\section{J. Torgersen svarer:}

Negative virkemidler er i altfor lang tid blitt brukt i spesialiseringen av leger. Midlertidig ansettelse av leger i spesialisering har vært brukt som et slikt virkemiddel i et forsøk på å forhindre propper i spesialiseringssystemet. Gjersvik beskriver i sin kommentar i Tidsskriftet nr. 8/2012 (1), publisert først på nett 30.3. 2012, rekrutteringsproblemer i hudfaget $\mathrm{i}$ dagens situasjon. Med andre ord har ikke midlertidighet som virkemiddel hatt den ønskede effekten på fordeling av leger. I tillegg har midlertidig ansettelse en rekke negative konsekvenser - både for fagmiljøene, for den enkelte avdeling og for den enkelte lege. Langsiktighet bidrar til bedre fagutvikling, bedre pasientsikkerhet og ikke minst bedre spesialisering.

For å sikre en bærekraftig og fremtidsrettet innføring av flere faste stillinger for leger i spesialisering i norske sykehus har det vært tenkt på en rekke forhold. For det første skal det gis ansettelse ved første ledighet, og fortrinnsrett ved ansettelse bortfaller. For det annet er det anbefalt en modell hvor man starter innfasingen av flere faste stillinger i gruppe II-sykehus, deretter ved større sykehus etter hvert. Dette vil gi arbeidsgiver flere virkemidler å bruke i innfasingen. For det tredje må antall stillinger dimensjoneres både $i$ et kortsiktig og i et langsiktig perspektiv. Man må først dimensjonere antallet faste stillinger på henholdsvis gruppe II og gruppe I, slik at det blir plass til alle som har behov for tjeneste andre steder enn der man er fast ansatt. Dernest må man dimensjonere det antall spesialiseringsstillinger som er nødvendig for å fylle det fremtidige behovet for antall spesialister.

Det er all grunn til å tro at faste stillinger også vil føre til færre vikariater, men ikke som eneste tiltak. For det første innebærer ansettelse innenfor samfunnets hovedregel - fast stilling - at gulvet løftes. I dag er ansettelsesnormen gjort uklar av arbeidsgiver som ansetter i stadig kortere stillinger. Fast ansettelse gir arbeidsgiver færre holdepunkter for å benytte ulovlige vikariater, slik det i stor grad finnes eksempler på i dag. I tillegg klargjøres det ved samarbeidsordninger hvor den enkelte skal gjennomføre sin spesialisering. Dette vil strømlinjeforme spesialiseringen og gi færre vikariater. Arbeidet med å rydde i ulovlig vikariatbruk vil fortsette og vil forløpe parallelt med implementeringen av faste stillinger. Lovlige vikariater må vi akseptere grunnet lovmessige og avtalemessige fraværsårsaker.

Det er fremtidsrettet å komme bort fra de negative incitamentene som ligger i ordningen i dag. Vi må komme over på positive virkemidler for å rekruttere leger til nødvendige deler av helsetjenesten. Faste stillinger er derfor en meget god idé - for pasientene, for fagmiljøene og for den enkelte lege.

\section{Johan Torgersen}

Yngre legers forening

Johan Torgersen (f. 1974) er spesialist i anestesiologi og ph.d. fra Universitetet i Bergen. Han har vært tillitsvalgt i Yngre legers forening (Ylf) siden 2007 og har nå permisjon fra stillingen som lege i spesialisering ved Haukeland universitetssykehus for å være leder i foreningen. Torgersen er også medlem av Legeforeningens sentralstyre.

Ingen oppgitte interessekonflikter.

\section{Litteratur}

1. Gjersvik P. Underordnet lege så lenge man selv vil. Tidsskr Nor Legeforen 2012; 132: 934.

\section{RETTELSE}

Ginkgo biloba - effekt, bivirkninger og interaksjoner

Pål-Didrik Hoff Roland, Cecilie Sogn Nergård

Tidsskr Nor Legeforen 2012; 132: 956-9

I Tidsskriftet nr. 8/2012, side 957, figur 1: Bildet viser ikke Ginkgo biloba, men Adiantum raddianum. Korrekt bilde publiseres her.

I figurteksten skal det stå: Ginkgo biloba.

Vi beklager feilen. Den er rettet i nettutgaven.

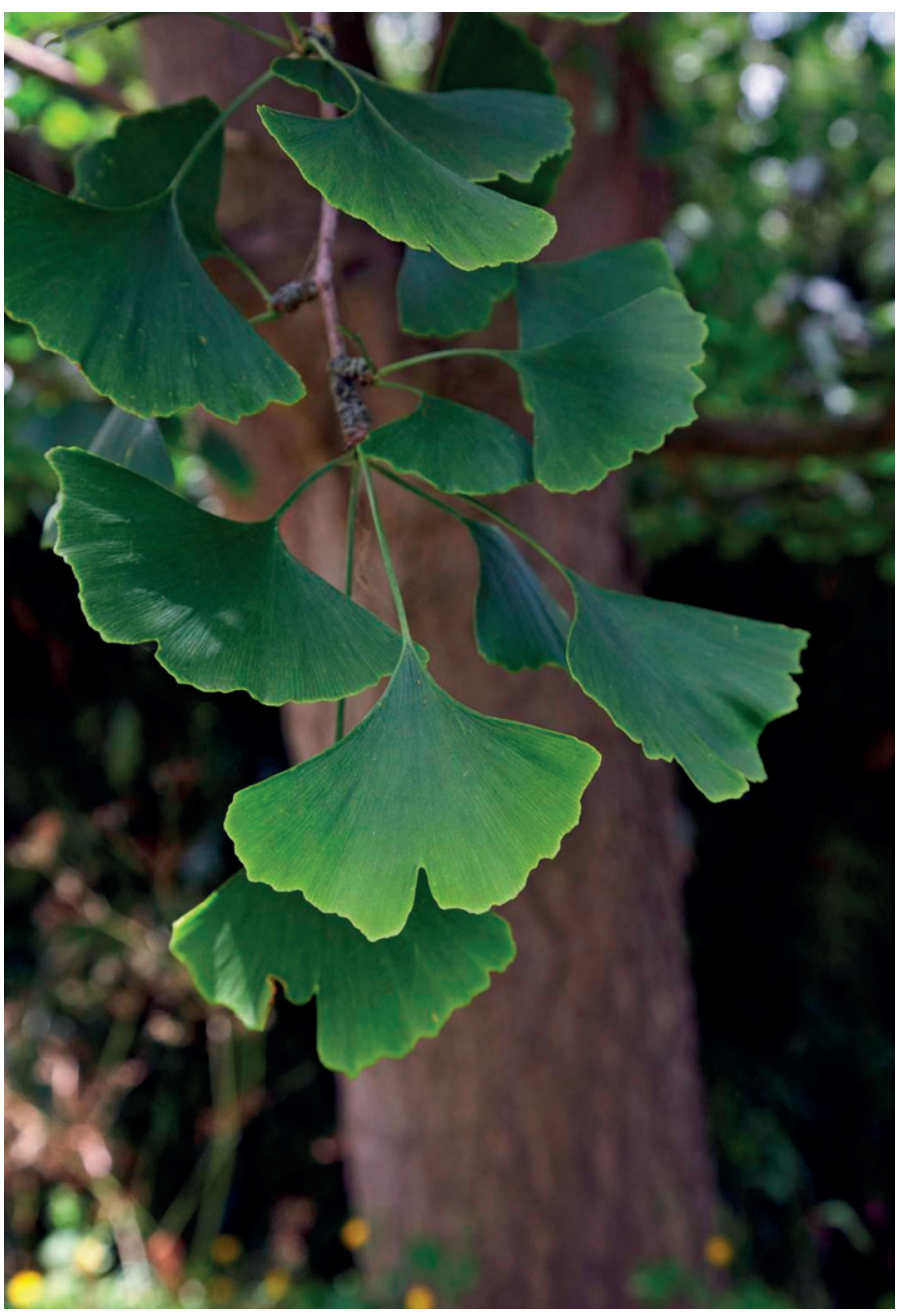

Samfoto/NTB scanpix 